\title{
Perspektif Puisi "A Dream Within A Dream" Pada Desain Fashion dan Lifestyle Homespun Spring Summer 2021
}

\author{
Refsi Venny Utomo ${ }^{1 *}$, Wyna Herdiana ${ }^{1}$, Dian Prianka ${ }^{1}$ \\ ${ }^{1}$ Fakultas Industri Kreatif, Universitas Surabaya, Raya Kalirungkut,-Surabaya 60293 \\ *corresponding author: vennyutomo@gmail.com
}

\begin{abstract}
A Spring/Summer 2021 collection based on WGSN trend forecast for Spring/Summer 2021 called HomeSpun, which inspired from Edgar Allan Poe's poem, "A Dream within a Dream". This poem consists of 24 rows which divided into two stanzas, illustrate the differences between our perception of lives and the effect of time, that emphasize human existencies are only dreams and illusions, an abstract picture from human mind. Clothes category are citywear with sophisticated and elegant looks. Using indepth interview, some keywords are produced, namely blurry, contention, curved lines, encounter of two different substances, conflicting diagonal line, and transparant. That keywords then poured into garment's cutting, details, and embellishments. The collection's details and embellishments are deconstructed cutting, plaits, embroidery texts, crochet, and clay beads. This collection consists of 60 designs of menswear, womenswear, and kidswear, also its lifestyle products and accessories. 5 looks consists of 14 garments, 5 pieces of shoes, 2 bags, 2 earrings, 2 glasses, 3 headbands, 1 set of hair clip, 1 bracelet, 1 scrunchies, and 1 handphone \& airpods case were realized.
\end{abstract}

Keywords: blurry, conflicting diagonal line, contention, two realities

\begin{abstract}
Abstrak-Perancangan koleksi Spring/Summer 2021 berdasarkan trend forecast WGSN Spring/Summer 2021 "HomeSpun" menggunakan inspirasi dari puisi karya Edgar Allan Poe, "A Dream within a Dream". Puisi ini mempunyai 24 baris yang dibagi menjadi dua bait, menceritakan perbedaan persepsi hidup kita serta efek waktu, yang menekankan bahwa eksistansi manusia hanyalah suatu impian dan ilusi, sebuah gambaran abstrak dari pikiran manusia. Kategori busana adalah citywear dengan kesan sophisticated dan elegan. Melalui metode penelitian wawancara, dihasilkan beberapa kata kunci, yaitu blurry, suatu pertentangan/bertolak belakang, garis lengkung, pertemuan antara dua substansi berbeda, conflicting diagonal line, serta transparan. Berbagai kata kunci tersebut kemudian dituangkan dalam cutting pakaian, detail, serta embellishments pada garmen. Detail dan embellishment yang dipakai adalah cutting yang sedikit deconstructed, anyaman, tulisan dengan menggunakan jahitan dan sulaman, serta rajutan dan clay beads. Koleksi ini terdiri dari 60 desain pakaian wanita, pria, serta anak perempuan dan berbagai produk lifestyle serta aksesoris pelengkapnya. Pakaian yang direalisasikan sebanyak 5 looks, yang terdiri atas 14 garmen, 5 pasang sepatu, 2 tas, 2 anting-anting, 2 kacamata, 3 headband, 1 set jepit rambut, 1 gelang, 1 scrunchie, serta 1 case handphone dan airpods.
\end{abstract}

Kata kunci: blurry, conflicting diagonal line, dua realita, pertentangan

\section{PENDAHULUAN}

Dunia ini semakin berkembang dengan segala kemajuan teknologi dan ilmu pengetahuan manusia. Dalam segala perkembangannya, dunia menjadi semakin kompleks dan manusia akan mencapai titik jenuh pada suatu waktu. Hal tersebut melahirkan tren baru yang semakin popular, yaitu tren minimalisme. Pergolakan ekonomi dunia serta persaingan di dunia kerja menyebabkan banyak orang mulai hidup dengan anggaran yang lebih kecil. Orang-orang lebih selektif dalam membeli barang serta lebih memilih untuk membelanjakan uang mereka untuk pengalaman daripada barang (Harveston, 2018). Kemajuan teknologi meningkatkan kesadaran manusia terhadap masalah-masalah sosial secara global, seperti ketidakadilan, kemiskinan, kelaparan, dan sebagaiannya. Hal inilah yang kemudian menjadi beberapa inspirasi dasar dari trend forecasting Spring/Summer 2021 "HomeSpun" yang dirilis oleh WGSN. HomeSpun mengutamakan penyederhanaan evolusi dengan emosi yang dalam dan desain yang menceritakan suatu kisah, bukan hanya desain yang sempurna. Desain yang berkembang seiring dengan berjalannya waktu, dan kental dengan autentisitas, sejarah, serta kerajinan.

Edgar Allan Poe adalah seorang penulis, penyair, kritikus, serta editor Amerika yang terkenal. Ia dikenal sebagai penulis puisi dan cerita pendek, serta misteri (The Biography.com Editors, 2019). Salah satu puisi karya Edgar Allan Poe yang terkenal adalah "A Dream within a 
Dream", yang pertama kali dipublikasikan di kertas cerita mingguan Boston, dalam edisi 31 Maret 1849 (Sova, 2001). Puisi ini mempunyai 24 baris yang dibagi menjadi dua bait, menceritakan perbedaan persepsi hidup kita serta efek waktu, yang menekankan bahwa eksistansi manusia hanyalah suatu impian dan ilusi, sebuah gambaran abstrak dari pikiran manusia. Poe menggunakan metafora laut untuk pergolakan emosi dari pembaca puisi ini, dengan berbagai pertanyaan tentang realitas atau ilusi. "A Dream Within a Dream" mempunyai makna mendalam mengenai arti kehidupan bagi seorang manusia yang dituliskan dengan berbagai kiasan dan majas yang indah oleh Edgar Allan Poe. Makna puisi ini menghasilkan sebuah konsep desain yang melebur dengan trend forecast WGSN Spring/Summer 2021 "HomeSpun". Elemen-elemen yang terdapat pada puisi "A Dream Within a Dream", baik secara metafora maupun emosional dapat menjadi inspirasi bentuk, warna, serta pattern yang akan diaplikasikan dalam koleksi.

Berikut ini adalah puisi "A Dream Within a Dream".

Take this kiss upon the brow!

And, in parting from you now, Thus much let me avow--

You are not wrong, who deem

That my days have been a dream;

Yet if hope has flown away

In a night, or in a day,

In a vision, or in none,

Is it therefore the less gone?

All that we see or seem

Is but A Dream Within a Dream.

I stand amid the roar

Of a surf-tormented shore,

And I hold within my hand

Grains of the golden sand--

How few! yet how they creep

Through my fingers to the deep,

While I weep--while I weep!

o God! can I not grasp

Them with a tighter clasp?

o God! can I not save

One from the pitiless wave?

Is all that we see or seem

But A Dream Within a Dream?

Rumusan masalah penelitian ini adalah: bagaimana pengaplikasian inspirasi elemenelemen pada puisi "A Dream Within a Dream", baik secara metafora maupun emosional yang melebur dengan trend forecast Spring/Summer 2021 "HomeSpun" pada koleksi fashion wanita, pria, dan anak-anak, berikut produk lifestyle-nya, serta mewujudkan rancangan marketing dan branding strategy? Oleh karena itu dibuatlah koleksi dengan tujuan mewujudkan trend forecast Spring/Summer 2021 dengan tema besar "HomeSpun" dengan inspirasi utama "A Dream Within a Dream" baik secara metafora maupun emosional dalam wujud produk fashion dan lifestyle.

Ruang lingkup dari koleksi tersebut adalah pria dan wanita dengan usia 19-30 tahun dan anak perempuan usia 5-7 tahun, dengan penghasilan lebih dari Rp10.000.000 per bulan, serta mengikuti dan update terhadap trend fashion yang sedang berlangsung, menghargai seni dan budaya, dan tinggal di kota-kota besar di Indonesia. Warna untuk koleksi ini adalah warnawarna natural lautan seperti metafora dalam "A Dream Within a Dream", serta warna dari aspek emosional yang memberi efek ilusi dan realitas. Material yang digunakan untuk koleksi 
ini adalah kain natural seperti linen, katun, kain sintetis dan lusturous untuk menggambarkan ilusi, serta kain yang kaku dan tebal seperti wool untuk menggambarkan realitas.

\section{METODE}

Pengumpulan data bertujuan untuk mencari data-data guna melengkapi informasi dan memperdalam pengertian tentang puisi "A Dream Within a Dream" karya Edgar Allan Poe. Kemudian, data yang didapatkan akan dianalisis untuk dimengerti. Data diambil dengan menggunakan teknik wawancara dengan narasumber yang ahli dan mendalami Sastra Inggris. Wawancara dilakukan dengan salah satu dosen di Jurusan Sastra Inggris Universitas Kristen Petra yang mengajar di bidang Literary Genre. Kemudian berdasarkan sintesis wawancara, diketahui bahwa puisi dapat memiliki arti yang berbeda bagi orang yang berbeda. Tiap orang dapat memahami puisi dengan interpretasi dan pengertiannya masing-masing. Oleh karena itu, perlu dilakukan pengisian kuesioner untuk mendapatkan beberapa pemahaman lagi menurut orang yang berbeda.

Kuesioner dibagikan kepada tiga orang mahasiswa desain yang fasih menggunakan Bahasa Inggris, sehingga bisa didapatkan sudut pandang yang berbeda dari sisi sastra Inggris. Dari data yang telah dikumpulkan dari berbagai narasumber, dengan teknik pengumpulan data wawancara dan angket, didapatkan informasi sebagai berikut.

- Puisi ini tentang kebingungan dan ketakutan akan kehilangan sesuatu, kehidupan yang tidak nyata, menggambarkan kesedihan dan kemarahan.

- Puisi ini merupakan sebuah pertanyaan yang diajukan oleh penyairnya tentang realitanya. Sang penyair tidak tahu apakah sebenarnya kehidupan yang ia jalani selama ini nyata atau tidak.

- Ada kemungkinan hal tersebut karena pengaruh narkotika yang dipakai oleh penyair, sehingga ia masuk ke realita yang lain karena perasaan melayang-layang yang ditimbulkan oleh obat terlarang tersebut.

- Emosi yang dirasakan adalah takut, panik, sedih, gelisah, menyesal, mengasihani diri sendiri, patah hati, putus asa, dan betapa menyakitkannya hilangnya sebuah harapan.

- Warna yang menggambarkan puisi ini adalah coklat muda, nila, biru, merah, dan abuabu.

- Puisi mempunyai banyak arti, tergantung siapa yang mengintepretasikannya. Pengertian orang yang satu dengan orang yang lain dapat berbeda.

- Puisi "A Dream Within a Dream" ini mempunyai unsur imajeri (imagery) atau citraan, yang membuat pembacanya seakan-akan sedang berada di pinggir pantai dan sedang menatap di kejauhan.

Berdasarkan data yang telah dikumpulkan melalui metode In-Depth Interview dan juga pembagian kuesioner kemudian diolah dan dikembangkan. Pengembangan data tersebut bertujuan untuk memahami lebih dalam tentang hal-hal yang terkait dengan puisi "A Dream Within a Dream". Berikut ini adalah pengembangan data-data dengan menggunakan metode mind mapping. 


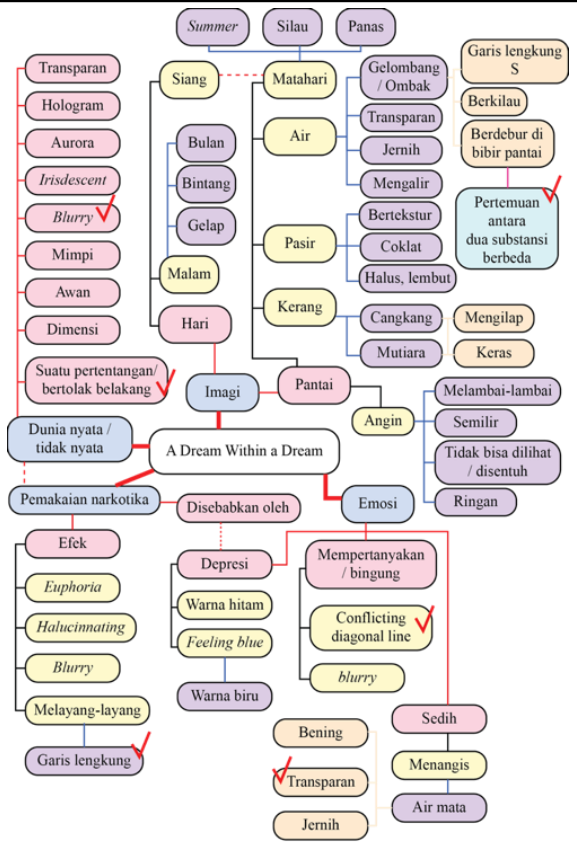

Gambar 1. Mind map hasil data.

Berdasarkan mind map tersebut didapatkan beberapa kata kunci. Kata kunci adalah kata-kata penting yang muncul beberapa kali maupun yang dapat menggambarkan inspirasi puisi "A Dream Within a Dream" secara garis besar. Kata kunci yang dipilih adalah blurry, suatu pertentangan/bertolak belakang, garis lengkung, pertemuan antara dua substansi berbeda, conflicting diagonal line, serta transparan. Kata kunci tersebut menjadi dasar dalam pembuatan desain koleksi ini.

\section{Blurry}

- Blurry berarti tidak jelas, buram, serta garis batas yang tidak terlihat jelas. Kata blurry didapatkan dari poin dunia nyata/tidak nyata, pemakaian narkotika, serta emosi bingung.

- Suatu pertentangan/bertolak belakang

- Kata ini didapatkan dari poin dunia nyata/tidak nyata. Antara dunia nyata dengan dunia yang tidak nyata adalah suatu hal yang bertentangan, saling bertolak belakang satu sama lain. Pengaplikasiannya dapat berupa penggunaan bahan yang berbeda karakteristiknya.

2. Garis lengkung

Garis lengkung didapatkan dari poin pemakaian narkotika dan imagi air laut yang berombak. Pengaplikasiannya dapat berupa garis lengkung tubuh yang terlihat atau dalam cutting.

3. Pertemuan antara dua substansi berbeda

Kata ini didapatkan dari poin imagi pantai dari puisi "A Dream within a Dream". Di bibir pantai, terjadi pertemuan antara dua hal yang berbeda, yaitu pasir dan air laut. Dalam pengaplikasiannya dapat berupa menggunakan bahan yang berbeda karakteristiknya.

4. Conflicting diagonal line

Kata ini merupakan penggambaran dari emosi bingung. Garis-garis yang bersilangan dapat diaplikasikan melalui detail dan embellishment serta shape dari garmen.

5. Transparan

Kata transparan didapatkan dari poin emosi sedih, dunia nyata/tidak nyata, serta imagi air laut. 


\section{HASIL DAN BAHASAN}

Stilasi adalah kegiatan mengubah bentuk suatu objek dan diberikan penggayaan, tanpa meninggalkan bentuk aslinya. Melalui proses stilasi dapat dihasilkan garis dan bentuk yang dapat diaplikasikan dalam desain. Objek yang akan distilasi didapat dari poin-poin penting hasil analisa data. Sintesis data menghasilkan poin pertemuan dua substansi yang berbeda, yang digambarkan dengan garis pantai. Poin lainnya yaitu emosi bingung, yang digambarkan dengan garis diagonal bersilangan, Serta bentuk tipografi dari puisi itu sendiri, yaitu kata-kata.

Tabel 1

Stilasi dari Hasil Pengembangan Data

\section{Objek Perwakilan}

Garis pantai

Dari gambar garis pantai, terdapat bentuk garis lengkung yang tidak beraturan.
Gambar Inspirasi

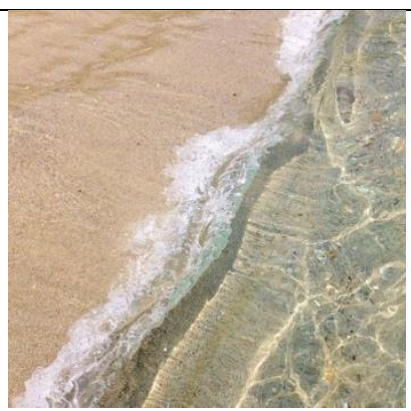

\section{Stilasi}

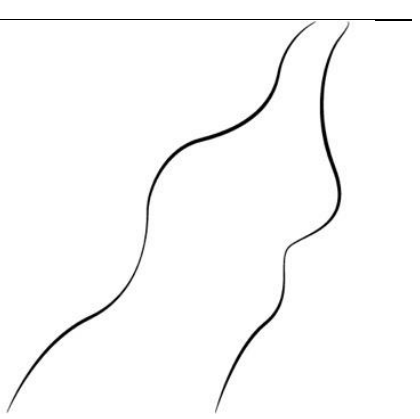

\section{Permukaan air laut}

Dari gambar permukaan air laut yang jernih dan terkena sinar matahari, didapatkan garis-garis lengkung yang tidak beraturan.
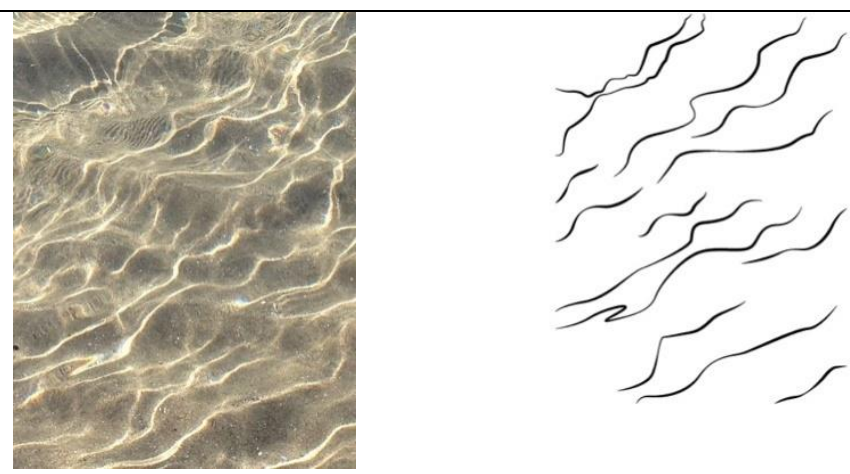

\section{Emosi bingung}

Penggambaran emosi bingung adalah dengan garis diagonal yang saling bersilangan, menyebabkan motif seperti berikut.



\section{Mimpi}

Penggambaran dari mimpi atau dunia yang tidak nyata bisa bermacam-macam dan abstrak.

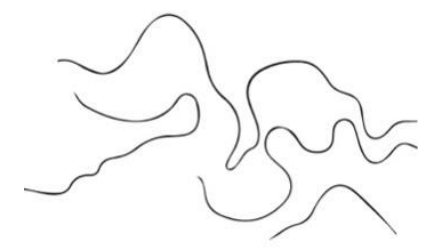


Text

Merupakan bentuk fisik

dari puisi, yaitu untaian

kata.

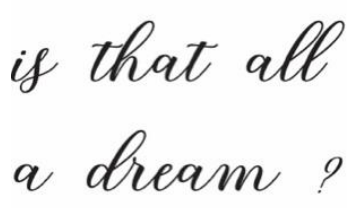

Dari hasil stilasi tersebut dilakukan beberapa eksperimen detail dan embellishments. Berikut ini hasil dari eksperimen tersebut.

\section{Tabel 2}

Hasil Eksperimen Detail dan Embellishments

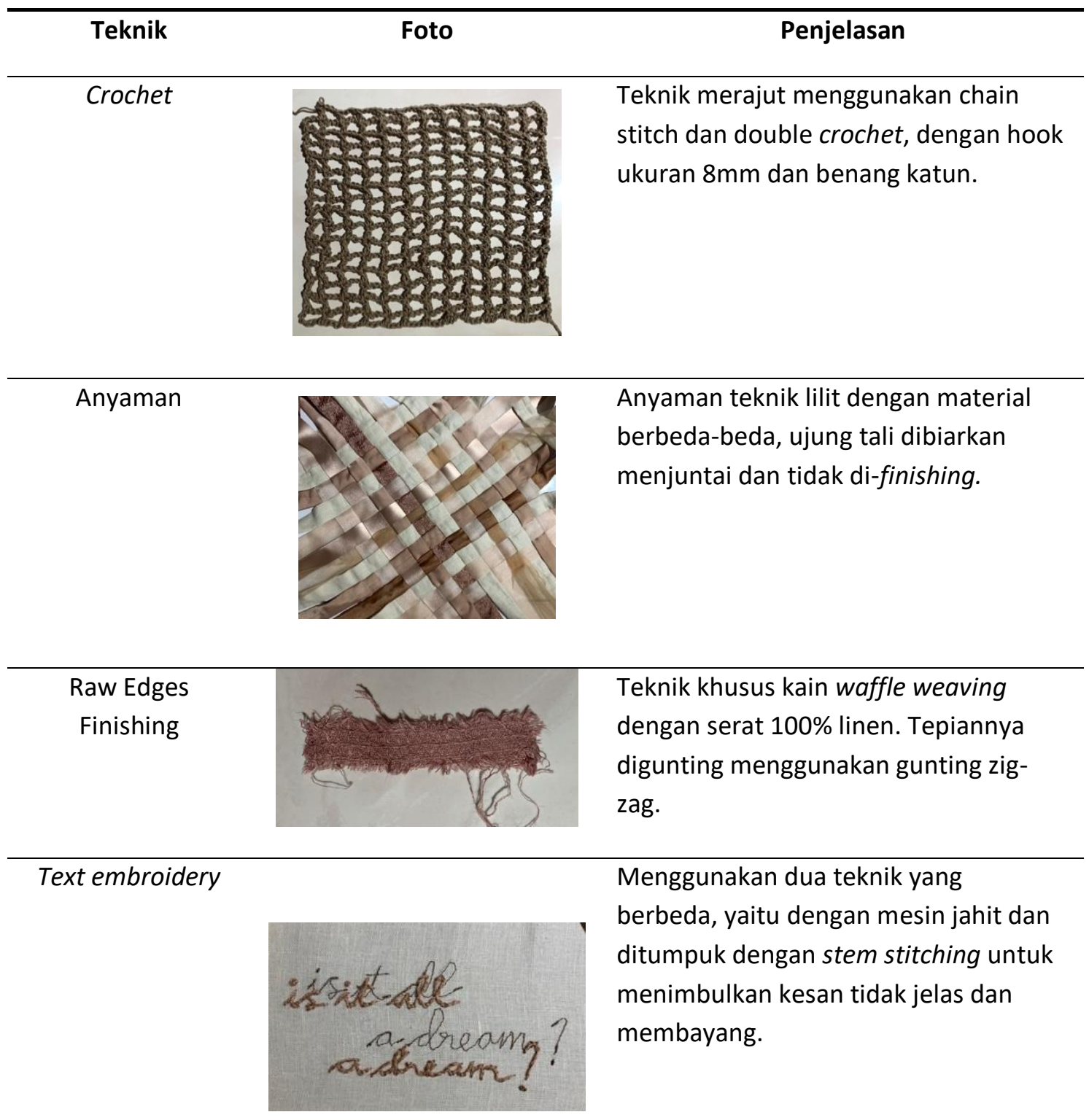




$\begin{array}{lll}\text { Teknik } & \text { Foto } & \text { Penjelasan }\end{array}$

Clay Beads

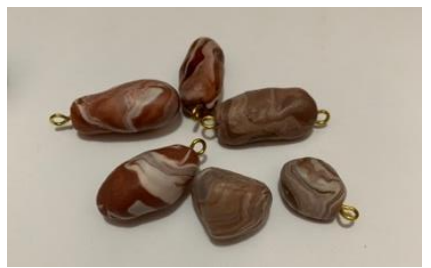

Beads dari bahan polymer clay dengan efek marble.

Koleksi ini mempunyai tiga segmentasi, yaitu pria, wanita, dan anak-anak. Masingmasing terdapat 20 alternatif desain yang menampilkan kesan elegan, sehingga total terdapat 60 alternatif desain. Dari semua alternatif, dipilih lima desain untuk direalisasikan. Desain terpilih berupa dua desain untuk pakaian wanita, dua desain untuk pakaian pria, serta satu untuk anak perempuan. Busana yang dipilih mempunyai style yang sesuai dengan style elegan dan sophisticated city wear. Setiap desain menggambarkan kata kunci yang didapatkan dari hasil penelitian berdasarkan inspirasi puisi "A Dream within a Dream".

Tabel 3

Analisis Desain Terpilih

Look

Look 1

Look 2

\section{Desain}
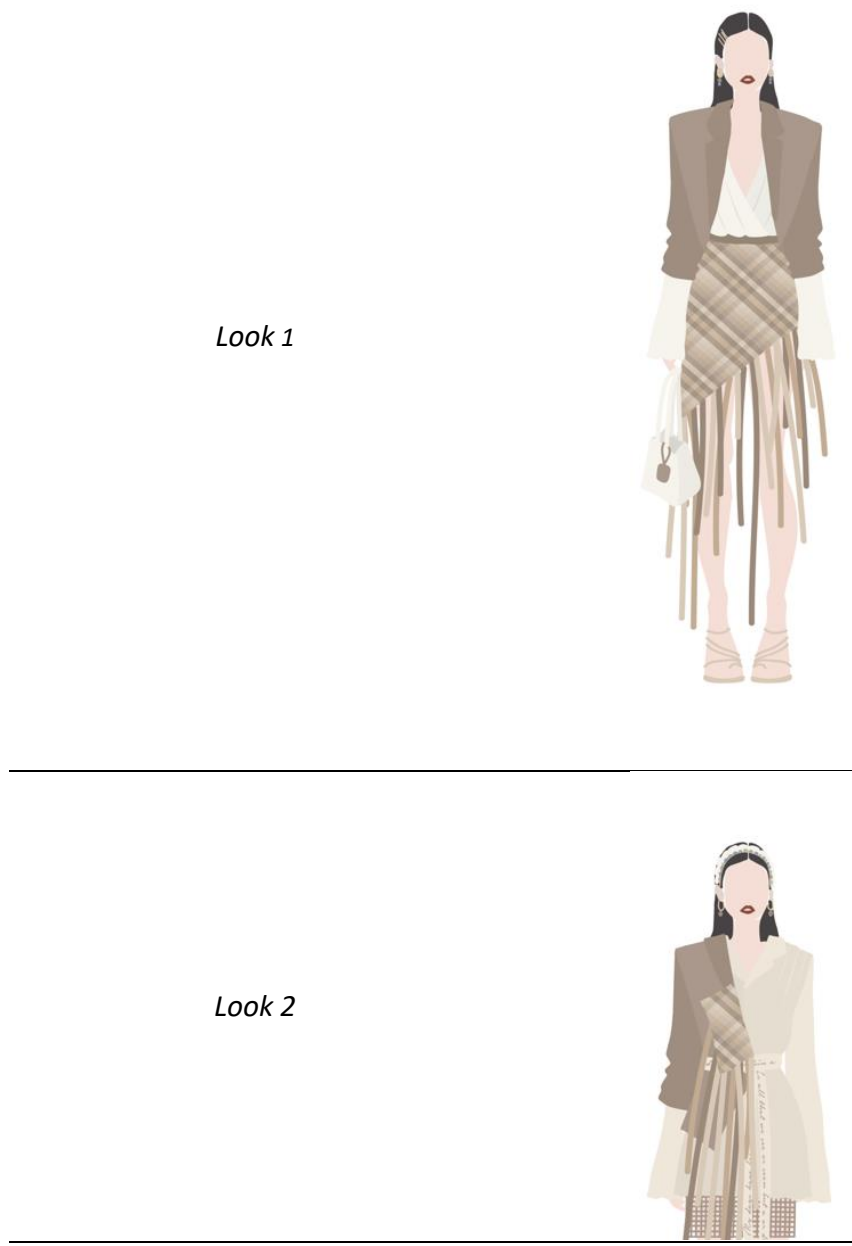

\section{Analisis Desain}

Outerwear berupa blazer dengan padding di pundak, dengan detail anyaman asimetris pada penutup kantong depan. Anyaman yang asimetris menimbulkan kesan antara dua realita, yaitu nyata dan tidak nyata. Blazer ini memiliki detail slit pada bagian belakang. Material yang digunakan adalah kain berbahan poliester dengan corak lurik.

Atasan dengan neckline berbentuk wrap yang terdraperi, menggambarkan dunia mimpi yang mengalir dan abstrak. Lengannya berbentuk terompet panjang, sehingga menimbulkan kesan flowy. Material yang digunakan adalah satin dengan finishing keemasan.

Bawahan berupa rok asimetris yang terbentuk dari anyaman. Rok ini dilengkapi dengan celana pada bagian dalamnya. Openingnya berupa invisible zipper pada bagian samping.

Outerwear berupa blazer asimetris dengan padding di pundak, dengan detail anyaman pada bagian depan. Bentuk blazer yang asimetris menimbulkan kesan antara dua realita, yaitu nyata dan tidak nyata. Blazer ini memiliki detail potongan pada bagian depan. Material yang digunakan adalah kain berbahan poliester dengan corak lurik.

Atasan berbentuk shirt dress dengan notch collar. Lengannya berbentuk 
terompet panjang hingga mau menutupi jari. Terdapat detail lipit di pundak. Finishing yang digunakan untuk hemline adalah raw edges finishing. Material yang digunakan adalah kain berbahan linen dengan sedikit campuran poliester.

Bawahan berupa rok rajutan yang dibuat dari benang katun halus. Rajutan dijahit pada panel yang kemudian diberi karet sebagai opening pada pinggang.

Tabel 3 berlanjut

Look 3

Look 4
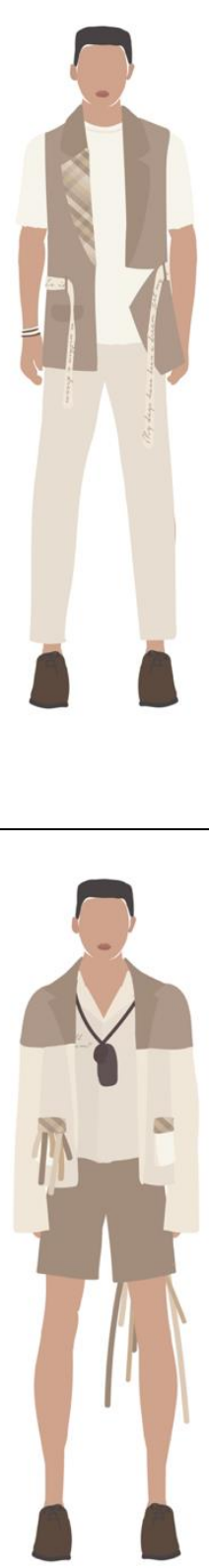

Outerwear berupa blazer asimetris tanpa lengan dengan detail anyaman pada kerah bagian depan. Bentuk blazer yang asimetris menimbulkan kesan antara dua realita, yaitu nyata dan tidak nyata. Blazer ini memiliki detail potongan pada bagian depan. Material yang digunakan adalah kain berbahan poliester dengan corak lurik. Dilengkapi dengan sabuk dari bahan poli linen dengan detail tulisan.
Atasan berbentuk shirt dengan detail kancing pada bahu. Finishing yang digunakan untuk hemline adalah raw edges finishing. Material yang digunakan adalah kain berbahan katun dengan tekstur waffle cloth.

Bawahan berupa celana panjang dengan detail panel lipatan asimetris pada hem line celana. Material yang digunakan adalah katun stretch dan poliester dengan corak lurik.

Outerwear berupa jaket dengan yoke yang berbeda warna. Terdapat detail anyaman asimetris pada penutup kantong depan. Anyaman yang asimetris menimbulkan kesan antara dua realita, yaitu nyata dan tidak nyata. Material yang digunakan adalah kain berbahan poliester dengan corak lurik dan katun stretch.
Atasan berbentuk shirt dengan detail notch collar. Finishing yang digunakan untuk hemline adalah raw edges finishing. Terdapat detail tulisan pada bagian depan. Material yang digunakan adalah kain berbahan poli linen.

Bawahan berupa celana pendek dengan detail kantong asimetris pada bagian belakang. Material yang digunakan adalah poliester dengan 
corak lurik.

\begin{tabular}{|c|c|}
\hline & $\begin{array}{l}\text { Atasan berbentuk sleeveless shirt } \\
\text { dengan opening berupa invisible } \\
\text { zipper. Material yang digunakan } \\
\text { adalah kain berbahan katun dengan } \\
\text { tekstur waffle cloth. }\end{array}$ \\
\hline Look 5 & $\begin{array}{l}\text { Bawahan berupa celana pendek } \\
\text { dengan detail potongan asimetris } \\
\text { pada bagian depan. Terdapat detail } \\
\text { anyaman pada satu sisi, yang } \\
\text { menggambarkan perbedaan dunia } \\
\text { nyata dan tidak nyata. Material yang } \\
\text { digunakan adalah poliester dengan } \\
\text { corak lurik. }\end{array}$ \\
\hline
\end{tabular}

Branding adalah nama, pesan, dan rancangan yang digunakan untuk mengidentifikasi suatu produk pada kelompok penjual, sebagai suatu pembeda dengan produk pesaing. Identitas visual adalah tampilan brand secara visual, baik berupa warna khas, bentuk, logo, layout khas, dan lain-lain.

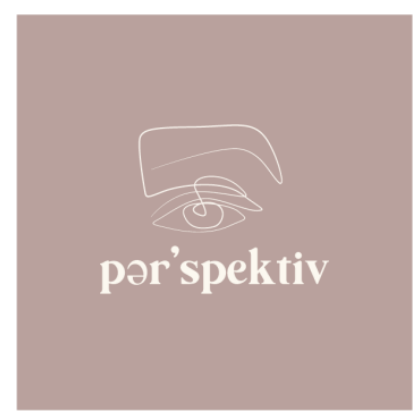

Gambar 2. Logo brand Parspektiv.

Pərspektiv berasal dari kata bahasa Inggris perspective, yang berarti sudut pandang seseorang dalam menanggapi sesuatu. Brand Pərspektiv memproduksi produk yang dibaliknya mempunyai cerita, yang kemudian dapat ditafsirkan melalui sudut pandang konsumen masingmasing. Pərspektiv ingin menampilkan bahwa setiap orang mempunyai cerita yang berbeda, semua orang mempunyai sudut pandang dan opini masing-masing. Pada logo brand, gambar mata merupakan simbol dari sudut pandang masing-masing orang. Teknik gambar yang dipakai adalah single continuous line drawing, yaitu satu garis yang berkesinambungan. Teknik ini dipilih karena menghasilkan gambar dengan style minimalis dan simpel serta modern.

\section{SIMPULAN}

Dalam merancang suatu koleksi dibutuhkan riset secara mendalam agar dapat merancang busana dengan lebih maksimal. Dari inspirasi puisi "A Dream within a Dream" oleh Edgar Allan Poe, penulis merancang 60 busana dan memproduksi lima looks. Puisi ini mempunyai 24 baris yang dibagi menjadi dua bait, menceritakan perbedaan persepsi hidup kita serta efek waktu, yang menekankan bahwa eksistansi manusia hanyalah suatu impian dan ilusi, sebuah gambaran abstrak dari pikiran manusia.

Kategori busana adalah citywear dengan kesan sophisticated dan elegan. Beberapa kata kunci yang didapatkan dari beberapa metode pengumpulan data adalah blurry, suatu pertentangan/bertolak belakang, garis lengkung, pertemuan antara dua substansi berbeda, conflicting diagonal line, serta transparan. Berbagai kata kunci tersebut kemudian dituangkan dalam cutting pakaian, detail, serta embellishments pada garmen. Metafora laut pada puisi dapat ditemukan pada motif marble yang terdapat pada clay beads. Selain itu, juga dapat menggambarkan dunia mimpi yang abstrak. 
Namun, dikarenakan pada tahun 2020 ini terjadi pandemi karena virus corona, timeline produksi serta peluncuran brand jadi terlambat. Diperlukan pula strategi marketing yang ter-update karena daya beli dan perilaku konsumen juga berubah akibat pandemi tersebut. Dapat disimpulkan bahwa dalam merancang suatu koleksi, riset tentang inspirasi telah dilakukan secara mendalam dan menyeluruh sehingga dalam setiap detail pakaian terdapat alasan dan cerita yang kuat dibaliknya, sesuai dengan salah satu poin penting trend forecasting Spring/Summer 2021 "HomeSpun", yaitu desain yang tidak hanya sempurna tetapi desain yang bercerita.

\section{PUSTAKA ACUAN}

Harveston, K 2018, Februari 15, 'Can the rising trend of minimalism help the environment?', retrieved from emagazine.com: https://emagazine.com/can-the-rising-trend-ofminimalism-help-the-environment/

Sova, D. (2001). Edgar Allan Poe: A to Z, Checkmark Books, New York.

The Biography.com Editors 2019, Agustus 1, 'Edgar Allan Poe biography', retrieved from Biography.com

\section{BIBLIOGRAFI}

Kant, R 2012, 'Textile dyeing industry an environmental hazard', Natural Science, 23.

Waluyo, H 1995, 'Teori dan apresiasi puisi', Erlangga, Jakarta.

Sumarni, M \& Soeprihanto, J 2010, 'Pengantar bisnis (Dasar-dasar ekonomi perusahaan)', Penerbit Libert, Yogyakarta.

Dillon, S 2011, 'The fundamentals of fashion management', A\&C Black. 